\title{
Usia dan Paritas Ibu dengan Insidence dan Derajat Bayi Baru Lahir (BBLR)
}

\author{
Dwi Ertiana ${ }^{1^{*}}$, Syifaa Urrahmah ${ }^{2}$ \\ ${ }^{1 * 2}$ Sekolah Tinggi IImu Kesehatan Karya Husada Kediri \\ * corresponding author \\ Dwi Ertiana \\ Kecamatan Pare Kabupaten Kediri Jawa Timur \\ ertiana.dwi@gmail.com
}

\begin{abstract}
Abstrak
Kehamilan usia < 20 tahun dan $>35$ tahun dengan paritas grandemulti dapat menyebabkan terjadinya BBLR. Usia dan paritas bukanlah penyebab utama dari BBLR, namun BBLR dipengaruhi oleh banyak faktor. Ibu yang berparitas tinggi dapat mengalami gangguan pada organ reproduksi khususnya pada alat kandungannya serta adanya gangguan pada pembuluh darahnya. Maka dari itu hendaknya seseorang merencanakan kehamilan pada usia reproduksi sehat yaitu usia 20 - 35 tahun untuk mengurangi kemungkinan terjadinya masalah-masalah pada saat kehamilan. Tujuan penelitian untuk mengetahui hubungan usia dan paritas ibu dengan insidence dan derajat BBLR di RSUD Kabupaten Kediri. Desain penelitian korelasional dengan pendekatan cross sectional, menggunakan data rekam medik. Populasi 2399 dengan menggunakan teknik simple random sampling dan memperhatikan kriteria inklusi dan eksklusi. Diperoleh sampel sebanyak 96, sampel diperoleh dengan perhitungan menggunakan rumus besar sampel Nursalam. Uji statistik spearman rank dengan nilai ó 0,05 . Hasilnya usia berisiko yaitu $31,3 \%$, paritas berisiko yaitu $50 \%$, sedangkan derajat BBLR yaitu $20,8 \%$. Hasil analisis penelitian antara usia dengan insidence dan derajat BBLR $(p$ value $=0,000<0,05) r$ $=0,440)$, paritas dengan insidence dan derajat BBLR ( $p$ value $=0,020<0,05) r=0,236$. Usia $<20$ tahun dapat menyebabkan BBLR dikarenakan ibu hamil usia $<20$ tahun rahim dan panggulnya sering kali pertumbuhanya belum maksimal. Sedangkan yang berusia $>$ 35 tahun ada perubahan jaringan organ reproduksi dan kelenturan jalan lahir. Paritas dapat menyebabkan terjadinya BBLR dikarena paritas yang tinggi mengakibatkan kerusakan dinding pembuluh darah uterus sehingga mengganggu aliran nutrisi ke janin yang menyebabkan terjadinya BBLR.
\end{abstract}

Kata kunci: Usia; paritas; bayi berat lahir rendah (BBLR)

\section{Age and Parity of Mother with Incidence and Degree of Newborn (LBW)}

\begin{abstract}
Pregnancy aged $<20$ years and $>35$ years with parity grandemulti can cause $L B W$. Age and parity are not the main causes of $L B W$, however $L B W$ is influenced by many factors. Mothers who have high parity can experience disorders of the reproductive organs, especially in the uterus as well as disorders of the blood vessels. Therefore, someone should plan a pregnancy at a healthy reproductive age, namely the age of 20 - 35 years to
\end{abstract}


reduce the possibility of problems during pregnancy. The research objective was to determine the relationship between maternal age and parity with insidence and degree of low birth weight in Kediri District Hospital. Correlational research design with cross sectional approach, using medical record data. Population 2399 using simple random sampling technique and paying attention to inclusion and exclusion criteria. Obtained a sample of 96, the sample was obtained by calculating the sample size formula Nursalam. Spearman rank statistical test with a value of $\alpha 0.05$. The result is that age at risk is $31.3 \%$, parity at risk is $50 \%$, while the degree of $L B W$ is $20.8 \%$. The results of the research analysis between age with insidence and degree of $L B W$ ( $p$ value $=0,000<0.05$ ) $r=0.440)$, parity with insidence and degree of $L B W(p$ value $=0.020<0.05) r=0.236$. Age $<20$ years can cause $L B W$ because pregnant women aged $<20$ years, the uterus and pelvis often have not yet maximized. Meanwhile, those aged> 35 years, there are changes in the reproductive organ tissue and the flexibility of the birth canal. Parity can cause LBW because high parity results in damage to the walls of the uterine blood vessels so that it interferes with the flow of nutrients to the fetus which causes $L B W$.

Keyword: Age; parity; low birth weight (LBW)

\section{Pendahuluan}

Di negara berkembang bayi berat lahir rendah (BBLR) merupakan masalah utama yang dialami oleh masyarakat (Bendhari \& Haralkan, 2015). Menurut WHO (2014) kejadian BBLR di negara berkembang yaitu 95\% dan di Asia Tenggara terjadi kelahiran dengan BBLR sebesar $11,6 \%$ dari data diseluruh dunia.

Menurut SDKI (2018) AKB di Indonesia yaitu 32 per 1.000 kelahiran hidup sedangkan untuk AKN sebesar 19 per 1.000 kelahiran hidup. 46,2 \% bayi di Indonesia meninggal ketika neonatus. Penyebab kematian bayi tertinggi adalah IUFD kemudian diikuti BBLR sebesar 1,2\% (Kepmenkes RI, 2015)
Data dari Dinkes Jatim pada tahun 2016 AKI di Jawa Timur yaitu 91/100.000 kelahiran hidup serta AKB sebesar 23,6/1.000 kelahiran hidup (Dinkes Jatim, 2018). Sedangkan berdasarkan data dari Dinkes Kabupaten Kediri penyebab kematian neonatus umur 0-7 hari pada tahun 2015 adalah asfiksia $44 \%$, BBLR $26 \%$, kelainan bawaan $20 \%$, trauma lahir $1 \%$, infeksi $4 \%$, dan lain-lain 4\% (Dinkes Kediri, 2018).

Menurut hasil penelitian Khoiriah (2017) didapatkan hasil nilai $p$ value $=$ $(0,003) \leq \alpha(0,05)$, bahwa terdapat hubungan antara usia ibu dan kejadian BBLR. Nilai $\mathrm{OR}=4,3 \mathrm{di}$ mana responden memiliki usia tidak 
reproduktif berisiko 4,3 kali lebih besar mengalami BBLR dibandingkan dengan usia tidak berisiko. Sedangkan dari penelitian yang berhubungan antara paritas ibu dengan BBLR didapatkan hasil $p$ value $=(0,025) \leq \alpha(0,05)$ bahwa ada hubungan bermakna antara paritas dan BBLR. Nilai $\mathrm{OR}=3,02$ artinya responden dengan paritas tinggi berisiko $3,02 \times>$ terjadinya BBLR dibandingkan paritas rendah (Khoiriah, 2017).

Paritas, jarak kehamilan, darah tinggi, usia ibu, usia kehamilan, kehamilan kembar, perokok, pekerjaan yang berat, hidramnion, kurang gizi ketika hamil merupakan faktor yang berhubungan dengan BBLR (Maryuni, 2017).

Usia 20-35 tahun merupakan usia yang tidak berisiko dan aman pada saat hamil dan bersalin serta usia yang berisiko pada saat hamil yaitu apabila kurang dari 20 tahun dan lebih dari 35 tahun di mana apabila ibu hamil berusia kurang dari 20 tahun maka alat reproduksi ibu khususnya rahim belum sempurna sehingga dapat membahayakan janin yang dikandungnya dan bisa membahayakan ibu karena dapat menyebabkan perdarahan ketika bersalin dan bayi bisa mengalami BBLR. Pada ibu yang berusia lebih dari 35 tahun apabila hamil dan bersalin berisiko karena jalan lahir tidak elastis lagi serta ada perubahan pada organ reproduksinya sehingga akan membahayakan baik pada ibu maupun pada janinnya (Rochyati, 2013).

Ibu yang berparitas tinggi dapat mengalami gangguan pada organ reproduksi khususnya pada alat kandungannya serta adanya gangguan pada pembuluh darahnya, di mana kehamilan yang terjadi berkali-kali akan menyebabkan adanya kerusakan pada pembuluh darah ibu khususnya pada pembuluh darah yang ada di rahim ibu yang akan menyebabkan gangguan penyaluran nutrisi yang diberikan ke janin pada saat ibu hamil lagi serta dapat menyebabkan bayi BBLR (Winkjosastro, 2013).

Upaya dalam pencegahan terjadinya BBLR adalah dengan meningkatkan kunjungan ulang pada ibu hamil dengan kunjungan setiap ibu hamil minimal $4 x$ kunjungan ke tenaga kesehatan bisa dokter ataupun bidan untuk memantau perkembangan kesehatan ibu maupun janinnya. Menganjurkan 
lebih banyak istirahat bila kehamilan mendekati cukup bulan dan lebih banyak istirahat apalagi apabila ibu mengalami gangguan pada saat sedang hamil ini, hal ini dilakukan untuk menjaga kondisi ibu dan janin agar kehamilannya bisa berjalan dengan normal. Sebagai tenaga kesehatan khususnya bidan hendaknya selalu mengingatkan kepada pasangan suami istri untuk selalu mengusahakan supaya pada saat hamil jarak antara kehamilannya yaitu paling tidak 2 tahun, untuk menjaga agar organ reproduksi normal kembali sehingga dapat mengurangi gangguan-gangguan yang terjadi pada ibu ketika hamil nanti.

Penelitian ini sejalan dengan Andriani (2014) di mana terdapat hubungan antara paritas dan BBLR, penelitian ini mengunakan uji statistik spearman rank sedangkan penelitian Andriani menggunakan uji statistik Chi-Square dengan diperoleh $p$ value $=0,001(\mathrm{p}<0,05)$ yang berarti terdapat hubungan signifikan antara paritas responden dan BBLR, dengan nilai $O R=5,549$ yaitu responden yang memiliki paritas berisiko akan berpeluang $5 x$ melahirkan BBLR.
Sedangkan penelitian Nasla (2018) didapatkan dari teori terdapat hubungan antara paritas dengan BBLR yaitu ibu yang memiliki paritas 1 dan $>4$ terdapat 10 ibu dari 210, mempunyai risiko melahirkan bayi dengan berat $<2500$ gram. Ibu yang baru melahirkan belum pernah mempunyai pengalaman sehingga organ uterus masih perlu untuk melakukan adaptasi hal tersebut yang dapat menyebabkan permasalah yang ada pada ibu dan bayi. Sedangan ibu yang memiliki bayi $>4$ dapat terjadi kesulitan pada saat hamil, sehingga mempengaruhi pertumbuhan dan perkembangan yang kurang maksimal, namun dari hasil penelitian Nasla tidak didapatkan hubungan antara paritas dan BBLR dengan nilai $p=0,805$.

Tenaga kesehatan dapat memberikan konseling kepada ibu untuk perencanaan kehamilan dan persalinan yaitu ketika ibu berusia 2034 tahun di mana organ reproduksi sehat pada usia tersebut. Kita sebagai tenaga kesehatan juga harus terus memantau ibu apalagi bagi ibu yang berisiko untuk mengalami gangguan pada saat hamil khususnya apabila risikonya mengarah kepada lahirnya BBLR, hal 
itu harus segera dilaporkan, diawasi dan dirujuk ke pusat pelayanan kesehatan yang dapat menangani hal tersebut (Proverawati, 2010).

Penelitian ini sejalan dengan penelitiann Riyanti dan Sipayung (2018) bahwa terdapat keterkaitan antara usia ibu dengan kelahiran BBLR. Dari 26 ibu yang usianya berisiko terdapat $76,9 \%$ yang melahirkan bayi BBLR. Sedangkan untuk ibu yang tidak memiliki risiko hanya $36,0 \%$ yang melahirkan bayi dengan BBLR. Dari perhitungan statistik antara kelompok kasus dan kontrol didapatkan nilai $\mathrm{p}=0,001<$ $\alpha=0,05$, dengan nilai $O R=1,69 ; \mathrm{Cl}$ $0,57: 4,97$. Perbedaan penelitian ini dengan penelitian Riyanti dan Sipayung yaitu diujinya yang menggunakan chi square, sedangkan penelitian ini ujinya menggunakan spearman rank.

Sebagai tenaga kesehatan kita harus rajin untuk memberikan konseling dan penyuluhan kepada pasangan calon pengantin, ibu yang merencanakan kehamilan, ibu hamil untuk rajin memeriksakan kehamilannya dan merawat kehamilannya dengan baik. Serta mengkonsumsi makanan makanan yang bergizi sehingga dapat menyebabkan kehamilannya berjalan lancar dan sehat untuk ibu dan janinnya. Hal itu dilakukan untuk mengurangi terjadinya risiko tinggi sedini mungkin untuk menurunkan risiko lahirnya BBLR.

\section{Metode}

Penelitian ini adalah survei analitik dengan desain kohort retrospektif. Usia dan paritas merupakan variabel independen dalam penelitian ini dan untuk variabel dependen penelitian ini yaitu derajat BBLR.

Populasinya semua bayi di RSUD Kabupaten Kediri Tahun 2018 yaitu 2399 responden. Untuk jumlah sampelnya yaitu ada 96 responden di mana pengambilan sampelnya menggunakan teknik simple random sampling yang sebelumnya mempertimbangkan kriteria inklusi (bayi dengan rekam medik yang lengkap, bayi yang mengalami BBLR) dan kriteria eksklusi (bayi dengan kelainan konginetal (hidrocepalus, kelainan pada jantung, atresia ani dan labiopalatoskisis)). Sampel tersebut perhitungannya didapatkan dengan menggunakan rumus dari Nursalam. Kemudian didapatkan pembagian $\mathrm{BBL}$ yang mengalami 
BBLR 20 bayi dan BBL yang tidak mengalami BBLR ada 76 bayi.

Pengumpulan data dilakukan dengan menggunakan lembar pengumpul data yang diisi berdasarkan data rekam medik RSUD Kabupaten Kediri Tahun 2018.

Analisis bivariat dalam penelitian ini menggunakan uji korelasi spearman rank dan nilai $\alpha=$ 0,05 .

\section{Hasil dan Pembahasan}

Hasil

Tabel 1. Karakteristik Responden Berdasarkan Usia

\begin{tabular}{ccc}
\hline \multirow{2}{*}{ Usia Ibu } & \multicolumn{2}{c}{ Total } \\
\cline { 2 - 3 } & $\mathrm{n}$ & $\%$ \\
\hline Tidak Berisiko & 66 & 68,8 \\
Berisiko & 30 & 31,2 \\
\hline Total & 96 & 100
\end{tabular}

Sumber: Hasil penelitian, 2019

Menurut tabel 1 dari 96 responden, usia yang berisiko yaitu ada 30 (31,3\%) dan tidak berisiko 66 $(68,8 \%)$.

Tabel 2. Karakteristik Responden Berdasarkan Paritas

\begin{tabular}{ccc}
\hline \multirow{2}{*}{ Paritas } & \multicolumn{2}{c}{ Total } \\
\cline { 2 - 3 } & $\mathrm{n}$ & $\%$ \\
\hline Primigravida & 34 & 35,4 \\
Multigravida & 48 & 50,0 \\
Grandemulti & 14 & 14,6 \\
\hline Total & 96 & 100
\end{tabular}

Sumber: Hasil penelitian, 2019

Menurut tabel 2 di atas dari total 96 responden, hampir setengah dari responden dengan primigravida sebanyak 34 responden (35,4\%), setengah dari responden multigravida sebanyak 48 responden (50,0\%), dan sebagian kecil dari responden grandemulti sebanyak 14 responden $(14,6 \%)$.

Tabel 3. Karakteristik Responden Berdasarkan Derajat BBLR

\begin{tabular}{ccc}
\hline \multirow{2}{*}{ Derajat BBLR } & \multicolumn{2}{c}{ Total } \\
\cline { 2 - 3 } & $\mathrm{n}$ & $\%$ \\
\hline Tidak BBLR & 76 & 79,2 \\
BBLR & 13 & 13,5 \\
BBLSR & 5 & 5,2 \\
BBLER & 2 & 2,1 \\
\hline Total & 96 & 100 \\
\hline
\end{tabular}

Sumber: Hasil penelitian, 2019

Berdasarkan tabel di atas dari total 96 sampel didapatkan hampir seluruh responden tidak mengalami BBLR sebanyak 76 responden $(79,2 \%)$, dan yang mengalami BBLER sebanyak 2 responden $(2,1 \%)$.

Tabel 4. Tabulasi Silang Hubungan Usia Ibu dengan Insidence dan Derajat BBLR di RSUD Kabupaten Kediri Tahun 2018

\begin{tabular}{|c|c|c|c|c|c|}
\hline \multirow{3}{*}{ Usia Ibu } & \multicolumn{4}{|c|}{ Derajat BBLR } & \multirow[b]{2}{*}{$\Gamma$} \\
\hline & BBLER & BBLSR & BBLR & $\begin{array}{l}\text { Tidak } \\
\text { BBLR }\end{array}$ & \\
\hline & $\%$ & $\%$ & $\%$ & $\mathrm{n} \%$ & $\mathrm{n} \%$ \\
\hline Berisiko & 22,1 & $4 \quad 4,2$ & $8 \quad 8,3$ & 1616,7 & 3031,3 \\
\hline $\begin{array}{c}\text { Tidak } \\
\text { Berisiko }\end{array}$ & 0 & 11,0 & $5 \quad 5,2$ & 6062,5 & 6668,8 \\
\hline Total & 22,1 & $5 \quad 5,2$ & 1313,5 & 7679,2 & 96100 \\
\hline
\end{tabular}

Berdasarkan tabel di atas, sebagian kecil dari responden usia ibu yang berisiko mengalami BBLER sebanyak 2 responden $(2,1 \%)$ dan sebagian kecil dari responden usia ibu berisiko yang tidak mengalami BBLR sebanyak 16 responden $(16,7 \%)$. Sedangkan pada usia ibu tidak yang berisiko tidak ada satupun 
responden yang mengalami BBLER yaitu 0 responden $(0 \%)$ dan hampir seluruh responden di mana apabila usia ibu tidak berisiko bayi tidak lahir BBLR yaitu ada 76 (79,2\%).

$$
\text { Hasil analisis bivariat }
$$

menggunakan spearman rank didapatkan $r=0,440$ dengan $p$ value= $0,000, \alpha=0,05$. Sehingga $p<\alpha$ maka $\mathrm{H}_{0}$ ditolak yang artinya ada hubungan antara usia ibu dengan insidence dan derajat BBLR dengan nilai $r=0,440$ dengan nilai hubungannya sedang.

Tabel 5. Tabulasi Silang Hubungan Paritas lbu dengan Insidence dan Derajat BBLR di RSUD Kabupaten Kediri Tahun 2018

\begin{tabular}{|c|c|c|c|c|}
\hline \multirow{3}{*}{ Paritas Ibu } & \multicolumn{3}{|c|}{ Derajat BBLR } & \multirow[t]{2}{*}{$\sum$} \\
\hline & BBLEFBBLSF & BBLR & $\begin{array}{l}\text { Tidak } \\
\text { BBLR }\end{array}$ & \\
\hline & $n \quad \% \quad n \quad \%$ & $\mathrm{n} \quad \%$ & $\begin{array}{lll}\mathrm{n} & \% & \mathrm{~F} \\
\end{array}$ & $\%$ \\
\hline Grandemulti & $\begin{array}{llll}2 & 2,1 & 2 & 2,1\end{array}$ & $\begin{array}{ll}6 & 6,3\end{array}$ & $\begin{array}{lll}4 & 4,2 & 14\end{array}$ & 14,6 \\
\hline Multigravida & $\begin{array}{llll}0 & 0 & 1 & 1,0\end{array}$ & $2 \quad 2,1$ & 4546,948 & 50,0 \\
\hline Primigravida & $\begin{array}{llll}0 & 0 & 2 & 2,1\end{array}$ & $5 \quad 5,2$ & 2728,134 & 35,4 \\
\hline Total & $2 \quad 2,1 \quad 5 \quad 5,2$ & 1313,5 & 7679,296 & 100 \\
\hline
\end{tabular}

Berdasarkan tabel di atas, sebagian kecil dari responden paritas grandemulti yang mengalami BBLER sebanyak 2 responden $(2,1 \%)$ dan sebagian kecil dari responden grandemulti yang tidak mengalami BBLR sebanyak 14 responden $(14,6 \%)$. Sedangkan pada paritas primigravida tidak ada satupun responden yang mengalami BBLER yaitu 0 responden $(0 \%)$ dan hampir setengah dari responden primigravida bayi lahir tidak BBLR yaitu 27 $(28,1 \%)$.

Hasil analisis bivariat menggunakan spearman rank didapatkan $r=0,236$ dan $p$ value $=$ 0,020 pada $(\alpha)$ 0,05.Sehingga $p<\alpha$ maka $\mathrm{H}_{0}$ ditolak yaitu terdapat hubungan yang signifikan antara paritas ibu dan insidence serta derajat BBLR dengan nilai $r=0,236$ berarti tingkat hubungannya rendah.

\section{Pembahasan}

Hasil penelitian memberikan gambaran bahwa ada hubungan antara usia ibu dengan insidence dan derajat BBLR di RSUD Kabupaten Kediri tahun 2018.

BBLR merupakan bayi dengan usia kehamilannya kurang dari 37 minggu dengan BB yang sesuai dengan BB pada saat sedang hamil. Sedangkan KMK merupakan bayi yang BB lahirnya tidak sesuai dengan usianya pada saat ibu itu sedang hamil yang biasanya dinamakan KMK (Pantiawati, 2010).

Ibu yang memiliki usia $<20$ tahun makan berisiko sebesar 1,3 kali melahirkan bayi yang mengalami BBLR sedangan untuk ibu yang usianya $>35$ tahun akan berisiko 2,1 kali untuk melahirkan bayi yang 
mengalami BBLR. Untuk usia tersebut di mana organ reproduksinya yang belum sempurna dan sudah mengalami penurunan fungsi dibandingkan dengan ibu yang memiliki usia 20-35 tahun di mana organ reproduksi sehat (Kusparlina, 2016).

Penelitian ini sejalan dengan penelitiannnya Riyanti dan Sipayung (2018) bahwa terdapat keterkaitan antara usia ibu dengan kelahiran BBLR. Dari 26 ibu yang usianya berisiko terdapat $76,9 \%$ yang melahirkan bayi BBLR. Sedangkan untuk ibu yang tidak memiliki risiko hanya $36,0 \%$ yang melahirkan bayi dengan BBLR. Dari perhitungan statistik antara kelompok kasus dan kontrol didapatkan nilai $\mathrm{p}=0,001<$ $\alpha=0,05$, dengan nilai $O R=1,69 ; \quad C l$ 0,57:4,97.

Kasus dengan ibu yang lebih tua memiliki rata-rata berat lahir lebih rendah dari pada kontrol (dengan nilai OR 3.236, $p$ value $=0,005$ ). Usia ibu yang lebih tua dapat mempengaruhi berat badan bayi dan bisa melahirkan bayi BBLR (Dyck, et al, 2003).

Usia ibu yang berisiko $<20$ tahun dan >35 tahun mempengaruhi kelahiran bayi BBLR. Dengan nila $p=$ $0,005<\alpha=0,05$. Untuk ibu yang usianya $<20$ bisa melahirkan bayi dengan BBLR karena organnya reproduksi belum matang maka dapat mempengaruhi kesiapan untuk menerima kehamilannya. Ibu dengan usia $>35$ tahun organ reproduksinya telah mengalami penurunan fungsi sehingga menyebabkan bayinya lahir dengan BBLR (Nasla, 2018)

Usia usia $<20$ tahun dan $>35$ tahun merupakan usia yang mempengaruhi berat lahir bayi. Di mana usia $<20$ tahun organ reproduksinya belum sempurna, sedangkan apabila usia > 35 tahun maka banyak terjadi perubahan pada organ reproduksi khususnya adanya perubahan pada pembuluh darah dan terjadi penurunan dari fungsi hormon dari ibu sendiri. Di samping itu juga dapat mempengaruhi distribusi nutrisi yang diberikan ibu kepada janin tidak bisa maksimal. Ibu yang memiliki usia lebih tua juga akan berisiko dengan penyakit hipertensi di mana hal tersebut merupakan salah satu faktor risiko untuk terjadinya bayi lahir dengan BBLR. Untuk ibu yang memiliki usia< 20 tahun juga memiliki risiko mengalami KEK di mana hal tersebut merupakan faktor yang bisa 
menyebabkan BBLR pada bayi. (Nurmalasari, 2017).

Terjadi berbagai permasalahan pada sistem tubuh apabila bayi lahir dengan BBLR di mana keadaan tubuh dari bayi masih belum stabil. Bayi normalpun juga perlu melakukan adaptasi untuk membuat tubuhnya bisa menyesuaikan dengan lingkungan, apabila bayi lahir dengan BBLR maka bayi tersebut akan lebih kesulitan melakukan adaptasi dibandingkan dengan bayi yang normal karena ada berbagai keterbatasan dalam sistem tubuhnya. BBLR mudah terserang infeksi dan komplikasi. Pada BBLR sering terjadi berbagai masalah yaitu masalah pada susunan saraf pusat, gastrointestinal, pernafasan, jantung, hematologi, ginjal dan suhu tubuh (Andrian, 2014).

Hal ini sejalan dengan penelitian di atas, yaitu usia ibu $<20$ tahun serta $>35$ tahun mempunyai risiko lebih tinggi mengalami komplikasi selama kehamilan dan persalinan. Hamil di usia tersebut bukan berarti dilarang, karena hamil adalah hak dari setiap wanita, tetapi akan lebih baik jika seseorang merencanakan kehamilan pada usia reproduksi sehat yaitu usia 20 - 35 tahun untuk mengurangi kemungkinan terjadinya masalahmasalah yang tidak diinginkan, karena hamil pada usia reproduksi sehat dapat mengurangi risiko angka mordibitas dan mortalitas dibandingkan usia reproduksi tidak sehat.

Sedangkan pada hubungan paritas ibu terdapat hubungan yang signifikan antara paritas dengan insidence dan derajat BBLR di RSUD Kabupaten Kediri.

Terdapat hubungan antara paritas dan BBLR, didapatkan nilai uji statistik Chi-Square dengan diperoleh $p$ value $=0,001 \quad(p<0,05)$ yang berarti terdapat hubungan signifikan antara paritas responden dan BBLR, dengan nilai $\mathrm{OR}=5,549$ yaitu responden yang memiliki paritas berisiko akan berpeluang $5 x$ melahirkan BBLR (Andrian, 2014).

Paritas yang berisiko yaitu grandemultipara, di mana pada ibu yang pernah melahirkan lebih dari $3 x$ maka akan mempunyai risiko lebih besar untuk melahirkan bayi BBLR karena pada ibu tersebut sel otot mulai melemah dan sehingga alat reproduksi sudah turun, di samping itu ada kelemahan pada pembuluh darah khususnya pada rahim ibu, karena seringnya hamil dan bersalin. 
sehingga akan berisiko untuk melahirkan BBLR (Prawirohardjo, 2010)

Ibu yang berparitas tinggi dapat mengalami gangguan pada organ reproduksi khususnya pada alat kandungannya serta adanya gangguan pada pembuluh darahnya, di mana kehamilan yang terjadi berkali-kali akan menyebabkan adanya kerusakan pada pembuluh darah ibu khususnya pada pembuluh darah yang ada di rahim ibu yang akan menyebabkan gangguan penyaluran nutrisi yang diberikan ke janin pada saat ibu hamil lagi serta dapat menyebabkan bayi BBLR. (Winkjosastro, 2013)

Paritas lebih dari 3 yaitu grandemultipara memiliki risiko untuk mengalami komplikasi pada saat sedang hamil dan bersalin. Apabila ibu memiliki paritas 1 sering kali terjadi komplikasi dikarenakan ibu belum siap beradaptasi dengan masa kehamilannya, sehingga menimbulkan kecemasan berlebih yang mengakibatkan ibu menjadi stress dan berpengaruh pada perkembangan janin di dalam rahim sehingga dapat mengakibatkan ibu melahirkan bayi BBLR.
Ibu yang memiliki paritas 1 dan $>4$ terdapat 10 ibu dari 210, mempunyai risiko melahirkan bayi dengan berat < 2500 gram. Ibu yang baru melahirkan belum pernah mempunyai pengalaman sehingga organ uterus masih perlu untuk melakukan adaptasi hal tersebut yang dapat menyebabkan permasalahan yang ada pada ibu dan bayi. Sedangan ibu yang memiliki bayi $>4$ dapat terjadi kesulitan pada saat hamil, sehingga mempengaruhi pertumbuhan dan perkembangan yang kurang maksimal (Nasla, 2018). Berdasarkan penelitian yang dilakukan oleh Sulistyorini (2013) didapatkan bahwa $p$ value 0,003 dengan nilai $\mathrm{OR} 2,325$ yang memiliki makna terdapat hubungan antara BBLR dengan paritas ibu.

Menurut Dinar (2019), terdapat keterkaitan antara paritas dan BBLR, 23 ibu yang memiliki paritas 1 dan $>3$ melahirkan bayi dengan BBLR dengan nilai persentase 29,5 serta ibu yang paritasnya 2 dan 3 maka $20,5 \%$ melahirkan bayi dengan BBLR. Dari analisa yang telah dilakukan maka didapatkan ibu dengan paritas 1 dan $>3$ lebih banyak berisiko 26.594 kali lebih besar untuk melahirkan BBLR. Dibandingkan 
dengan ibu dengan paritas tidak birisiko yaitu 2 dan 3 . Nilai $p$ value $0,000<\alpha 0,05$ yang berarti terdapat keterkaitan antara paritas dan BBLR.

lbu yang baru melahirkan anak yang pertama tidak mengalami peningkatan insiden bayi yang lahir lebih besar dengan usia kehamilannya, namun akan meningkatkan insiden bayi yang lahir dengan BBLR (Schimmel, et al ,2015)

\section{Simpulan}

Terdapat hubungan signifikan antara usia dan paritas dengan insidence dan derajat BBLR di RSUD Kabupaten Kediri tahun 2018.

lbu yang memiliki usia $<20$ tahun dan $>35$ tahun memiliki risiko untuk melahirkan bayi BBLR, hal ini disebabkan bahwa apabila ibu usianya semakin tua maka akan terjadi perubahan pada organ reproduksi khususnya pada rahim ibu dan akan mempengaruhi penyaluran nutrisi yang akan diberikan kepada bayi. Penyaluran nutrisi tersebut tidak maksimal karena adanya perubahan pada pembuluh darah dan terjadi penurunan hormon pada. Pada ibu yang memiliki usia > 35 tahun memiliki risiko untuk mengalami darah tinggi, hal itu bisa menyebabkan ibu bisa melahirkan bayi BBLR.

Sedangkan ibu dengan paritas tinggi dapat menimbulkan risiko kerusakan pada dinding pembuluh darah uterus akibat kehamilan yang berulang-ulang sehingga dapat menyebabkan gangguan pertumbuhan janin dan mempengaruhi berat bayi pada saat lahir.

\section{Daftar Pustaka}

Andrian D. (2014). Hubungan Usia dan Paritas Ibu dengan Kejadian Berat Bayi Lahir Rendah (BBLR) di RSUD dr. Ahmad Mochtar Kota Bukittinggi. Internet Avaiable from: URL: http://ejournal.stikesyarsi.ac.id/ index.php/JAV1N1/article/view File/53/106. Accessed February 13, 2019

Dinkes Kabupaten Kediri. (2018).Tentang Penyebab Kematian Neonatus.. Internet Avaiable from: URL: https://www.google.com/searc h? client=firefox- $b-$ d\&q=Dinkes+Kabupaten+Kedir i. Accessed February 15, 2019

Dinkes Provinsi Jawa Timur. (2018). Profil Kesehatan Provinsi Jawa Timur Tahun 2016. Internet Avaiable from: URL: https://www.kemkes.go.id/reso urces/download/profil/PROFIL KES PROVINSI 2018/15 Ja tim 2018.pdf. Accessed February 15, 2019 
DKI. (2018). Survei Demografi Dan Kesehatan Indonesia 2017. Jakarta. Bada Kependudukan dan Keluarga Berencana Nasional

Dyck R, Klomp H, Tan L, Stang MR. (2003). An association of maternal age and birth weight with end-stage renal disease in Saskatchewan. Sub-analysis of registered Indians and those with diabetes Comparative Study. Am J Nephrol. 23(6):395-402. doi: $10.1159 / 000074066$.

PMID: 14555863.

Kepmenkes RI. (2015). Rencana Strategis Kementrian Kesehatan Tahun 2015-2019 dalam rencana strategi. 2015. Internet Avaiable from URL: http://www.depkes.go.id/resour ces/download/infopublik/renstra-2015.pdf.

Accessed Januari 12, 2019.

Khasanah DU. (2019). Faktor-Faktor Yang Berhubungan Dengan Kejadian Berat Badan Lahir Rendah (BBLR) di RSUD Sleman Yogyakarta. Internet Avaiable from: http://digilib2.unisayogya.ac.id/ xmlui/bitstream/handle/123456 789/579/Dinar\%20UK\%20\%28 1810104076\%29 Naskah\%20 Publikasi\%20PDF.pdf?sequen $\mathrm{ce}=1$ \&isAllowed $=y$. Diakses tanggal 29 Agustus 2019.

Khoiriah A. (2017). Hubungan Usia dan Paritas lbu Bersalin dengan Bayi Berat Lahir Rendah (BBLR) di Rumah Sakit Islam Siti Khadijah Palembang Tahun 2017. Internet Avaiable from: URL https://www.researchgate.net/p ublication/323984810 Hubung an Antara Usia dan Paritas lbu Bersalin dengan Bayi $\mathrm{Be}$ rat Lahir Rendah BBLR di $\mathrm{R}$ umah Sakit Islam Siti Khadii ah Palembang. Accessed February 15, 2019

Kusparlina, EP., (2016) Hubungan Umur dan Status Gizi Ibu Berdasarkan Ukuran Lingkar Lengan Atas dengan Jenis BBLR. 2016. Internet Avaiable from: URL: https://forikesejournal.com/index.php/SF/arti cle/view/8. Accessed Januari 11, 2019.

Maryuni A. (2013). Asuhan Kegawatdaruratan dan Penyulit pada Neonatus. In Media, Yogyakarta.

Nasla UE. (2018). Analisis Kejadian Berat Badan Bayi Baru Lahir Rendah (BBLR) Pada Bayi Baru Lahir di Kota Singkawang. Jurnal Kesehatan Prima. Volume 12, No $1 \mathrm{Hal}$ 61-72. Internet avaliable from: http://jkp.poltekkesmataram.ac.id/index.php/home Diakses tanggal 19 Maret 2019.

Nurmalasari. (2017). Gambaran Kejadian Bayi Berat Lahir Rendah (BBLR) Di Puskesmas Minggir Kabupaten Sleman Tahun 2015-2016. Avaiable from:

URL: https://fdokumen.com/docume nt/gambaran-kejadian-bayiberat-lahir-rendah-b-blr-hakinizepi-1114727nonfullpdf.html. Accessed February 15, 2019

Pantiwati, I., (2010). Bayi dengan BBLR (Bayi Berat Lahir Rendah). Nuha Medika. Yogyakarta. 
Prawirohardjo S. (2010). Buku Acuan National Pelayanan Kesehatan Maternal Neonatal. Jakarta: PT Bida Pustaka Sarwono Prawiroharjo.

Proverawati, A dan Ismawati C., (2010). Bayi Berat Lahir Rendah (BBLR). Yogyakarta: Nuha Medika

Riyanti R dan Sipayung NA. (2018). Faktor Risiko Yang Berhubungan Dengan Kejadian Bayi Berat Badan Lahir Rendah (BBLR) Pada Wanita Pekerja Petani Kopi di Kabupaten Bener Meriah. Journal Bidan KomunitasVol 1 No 1, 39-47. Internet avaliable From:

http://ejournal.helvetia.ac.id/ind ex.php/jbk/article/download/39 18/119. Diakses tanggal 13 Maret 2019.

Rochyati, P. (2013). Skrining Antenatal Pada lbu Hamil, Pengendalian Faktor Resiko, Deteksi Dini Ibu Hamil Resiko Tinggi.

Schimmel MS, et al. (2015). The effects of maternal age and parity on maternal and neonatal outcome. Journal Arch Gynecol Obstet. 291 (4): 793-8.

PMID: 25227657.

DOI: $10.1007 / 500404-014-$

3469-0.

Sulistyorini, S. (2013). Faktor-Faktor Yang Berhubungan Dengan Kejadian Bayi Berat Lahir Rendah Di Irna Kebidanan Dan Penyakit Kandungan RSUP Dr. Mohammad Hoesin Palembang. STIK Bina Husada Palembang. Jurnal Harapan Bangsa Vol.1 No.2 Desember 2013.
Winkjosastro, H. (2013). IImu Kebidanan. Yayasan Bina Pustaka Sarwono Prawirohardjo. Jakarta

World Health Organization (WHO). (2014) Infant Newborn. Internet Avaiable from: URL: https://www.who.int/infantnewborn/en/. Diakes tanggal 11 Maret 2019 